\title{
The Pattern of Sediment Dispersion in the Front Sector of the Stenhouse and Ajax Glaciers, Visca Anchorage, King George Island, Antarctica
}

\author{
Beatriz Ferraz Scigliano1, Kátia Kellem da Rosa ${ }^{2}$, Ana Teresa Cordeiro Cid Bastos'1, \\ Elisabete de Santis Braga ${ }^{1}$ \\ ${ }^{1}$ Instituto Oceanográfico da Universidade de São Paulo, Laboratório de Nutrientes, Micronutrientes e \\ Elementos Traço nos Oceanos-Praça do Oceanográfico, 191, CEP 055-8-120 Cidade Universitária, São Paulo, \\ Brazil \\ ${ }^{2}$ Universidade Federal do Rio Grande do Sul, UFRGS, Centro Polar e Climático-CPC, Departamento de \\ Geografia-Instituto de Geociências, Av. Bento Gonçalves, 9500, Porto Alegre, Brazil \\ Email: beatriz.scigliano@usp.br, ana.teresa.bastos@usp.br, edsbraga@usp.br, katia.rosa@ufrgs.br
}

Received 20 August 2014; revised 16 September 2014; accepted 12 October 2014

Copyright (C) 2014 by authors and Scientific Research Publishing Inc.

This work is licensed under the Creative Commons Attribution International License (CC BY). http://creativecommons.org/licenses/by/4.0/

c) (7) Open Access

\begin{abstract}
This study investigated the dispersal pattern of suspended sediment in the areas near the Stenhouse and Ajax glaciers, Visca Anchorage, Martel Inlet, King George Island, Antarctica. This study was conducted using visible band processing of Quickbird high-resolution spatial images obtained in October 2006. The methodology was also based on the collection and interpretation of data obtained from water samples collected in Admiralty Bay in December 2004. The digital processing of satellite images was performed using a classification method based on the reflectance characteristics of water. The classified images improved visual identification of the dispersion pattern of suspended sediments in the study area. These data were related to the interpretation of analyses conducted on suspended particulate matter (SPM) in the water. The sediment dispersal pattern observed may be associated with glacial erosion processes, their input of meltwater from the front of the glaciers into the study area, detritus flow processes and glaciomarine circulation in the region.
\end{abstract}

\section{Keywords}

Remote Sensing, Glaciomarine Circulation, Suspended Sediment 


\section{Introduction}

Climate change has been observed by several researchers studying the Antarctic continent, and one example of its effect is the retraction of some glaciers on the Antarctic Peninsula, such as the Stenhouse and Ajax glaciers, both located in the Martel Inlet on King George Island (Figure 1).

The ice masses on King George Island flow from the domes through drainage basins of varying sizes and topographical conditions.

At the Martel Inlet, glaciers located in areas with a steep surface gradient, such as the Ajax and Stenhouse glaciers, have relatively fast flow with many fractures. The breaking of the glacier fronts that flow into the inlet typically form growlers [1].

The climate on King George Island is determined by successive passages of cyclonic systems that mostly originating in the southeastern section of the Pacific Ocean. These systems bring relatively warm and moist air. The climate shows small variations in atmospheric temperature throughout the year and high relative humidity (approximately 82\%) [2] [3].

Over the past 30 years, the number of days per year with liquid precipitation in the summer and number of days when the mean temperature exceeded $0^{\circ} \mathrm{C}$ have both increased, which increase the melting of snow and ice from the island's glaciers [4] [5]. Since 1950, several authors have reported glacier retreat on the island [6]-[8] [9]. The pattern of glacial retreat reflects a trend toward atmospheric warming in the peninsula region since 1940 [1] [6] [10] [11].

Deglaciation-related changes cause significant alterations of the Inlet's sediment dynamics, thus affecting the marine ecosystems of these environments [12]. The data from this study therefore contribute to the ongoing monitoring of the region to track the effects of environmental changes and also contribute to investigations regarding how these changes influence glacial sedimentation processes in the study area. Martel Inlet, is in an important area for such research because it connects current glaciomarine sedimentation processes with processes controlled by climate and glaciological and oceanographic conditions.

The Admiralty Bay water body has complex hydrography with tide- and wind-driven currents that influence circulation in the fjord. Pruszak (1980) [13] described the circulation patterns of surface waters. In the initial 100 $\mathrm{m}$, the water layer has currents with a speed of 0.3 to $1.0 \mathrm{~m} \cdot \mathrm{s}^{-1}$. According to these data, as it reaches $4.0 \mathrm{~m} \cdot \mathrm{s}^{-1}$,

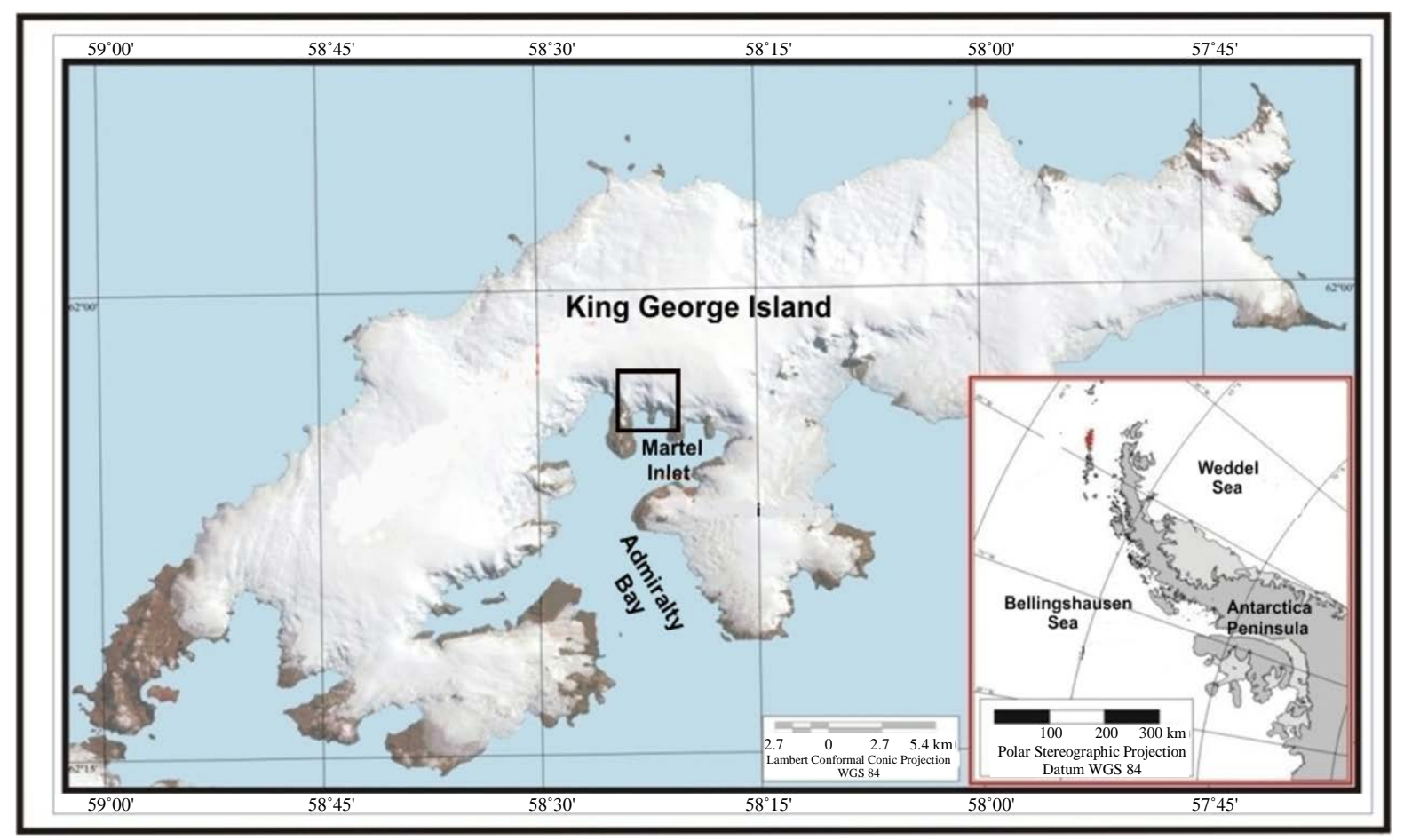

Figure 1. Location of the Martel Inlet on King George Island in the northwest sector of the Antarctic Peninsula. The area bounded in the red square shows the Visca Anchorage sector and the front of the Stenhouse and Ajax glaciers. 
wind has a great influence on surface water movements, and this influence reaches $30 \mathrm{~m}$ deep. The temperature on the shores of Admiralty Bay can reach $5.3^{\circ} \mathrm{C}$ in the summer, but in the vicinity of tidal glaciers, can be as low as $-1.6^{\circ} \mathrm{C}[2]$.

Water salinity changes markedly in the summer because of the intense inflow of meltwater. The presence of meltwater with high concentrations of suspended sediment contributes to the decrease in salinity [14].

These glaciomarine environments associated with tidal glaciers are characterized by their significant contribution of fine sediments, known as suspended sediment plumes, mixed with coarse sediments deposited by gravity flow in the area proximal to the endpoint of the glaciers [15]. The sediments circulate within the bay's water body and form a turbidity plume with maximum concentrations at depths of approximately 40 meters. The plume generation mechanisms are attributed to upwelling flows caused by subglacial melt currents (because of different degrees of water body densities penetrating the fjord), which rise to the surface layers, where they reach a plateau, and generate turbidity currents at medium depths and water masses of low salinity along the surface. A surface layer of less saline water is formed by melting surface snow from the glacier and liquid precipitation in the fjord, and the influence of this layer can extend to a depth of 75 meters [2] [14].

This study aims to analyze the pattern of sediment load dispersion in the water system in locations near exposed coastal portions and the Stenhouse and Ajax glaciers that flow into the Visca Anchorage, Martel Inlet, King George Island, Antarctica (Figure 1 and Figure 2).

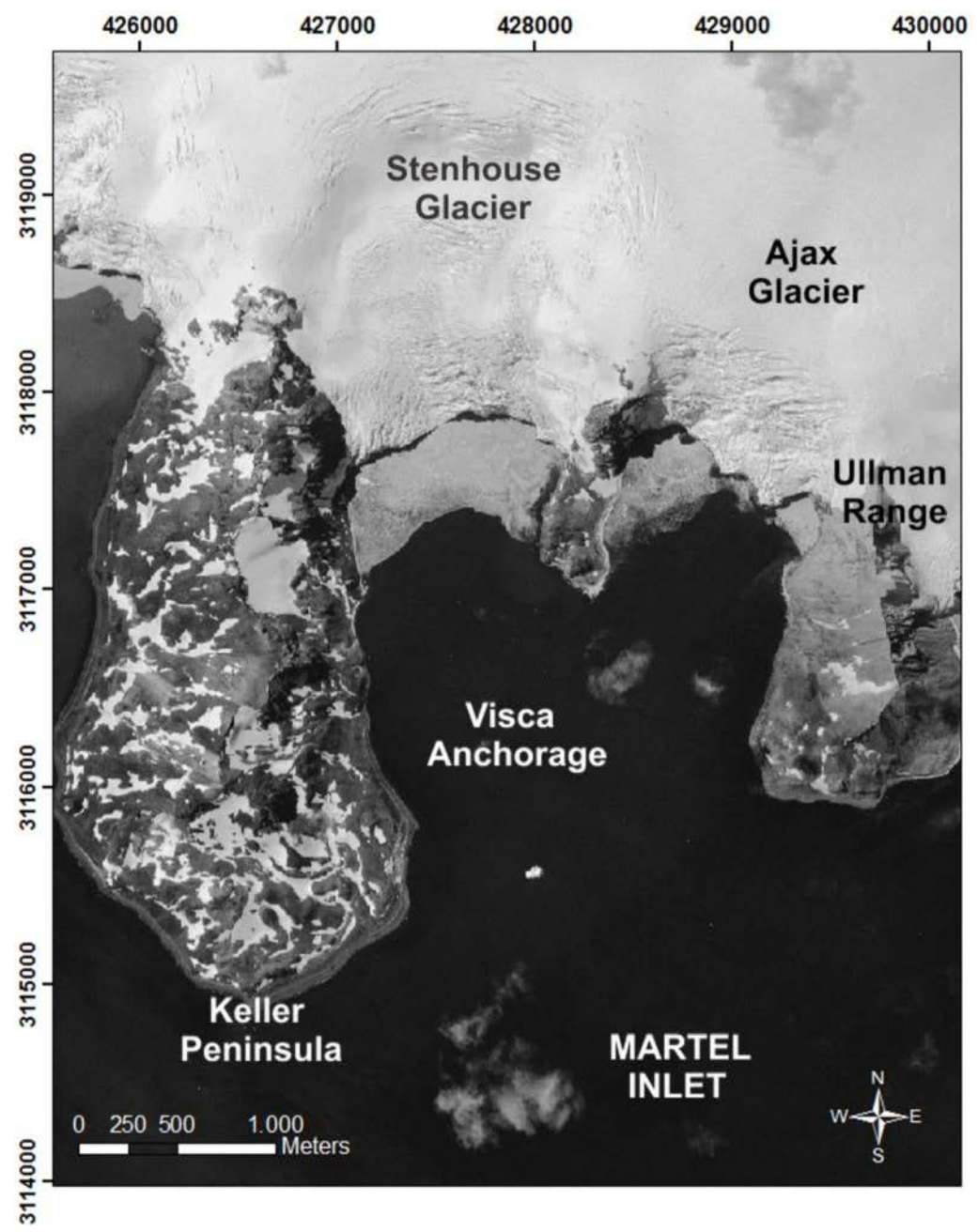

Figure 2. Visca Anchorage sector and the front of the Stenhouse and Ajax glaciers. Aerial photographs to generate this orthography were obtained in January 2003 by SHOA (Servicio Hidrográfico y Oceanográfico de La Armada del Chile). In the ablation period of 2003, there was sea ice formation along the front of the Ajax and Stenhouse glaciers. 


\section{Methodology}

Digital processing was performed with multispectral scenes of the QuickBird sensor, obtained in October 2006, with a spatial resolution of 0.61 and $2.4 \mathrm{~m}$. The image obtained with atmospheric correction was orthorectified using a UTM projection and WGS-84 datum. An image analysis based on linear enhancement techniques for better visualization of reflectance changes was performed with visible bands because of the reflectivity of sediment suspended in the water in this spectral range. Image classification was performed using an image segmentation technique to define the samples (training areas) by similarity thresholds between the pixels and the application of the Maximum Likelihood supervised classification algorithm using the parametric method. Geoprocessing techniques are an important spatial analysis tool that allows various geomorphological processes to be monitored, including spatial and temporal distribution patterns of suspended sediment in estuaries [16].

Sampling was conducted in association with the Brazilian Antarctic Program (PROANTAR) during OPERANTAR XXIII in December 2004 as a component of the HIDROGEOQUIMBA (Hidrogeoquímica da Baía do Almirantado-Hydrogeochemistry of Admiralty Bay) PROANTAR-LINE 2 Project, CNPq process number 550349/2002-2 under the responsibility of Dr. E. S. Braga. The work was performed on board the R/V Ary Rongel oceanographic support ship of the Brazilian Navy and the vessel "SKUA". A total of 26 oceanographic stations were established in Admiralty Bay and 4 specifically in Martel Inlet (Figure 3) where water samples were collected from the surface, middle and bottom layers for analysis of the following parameters: water temperature, salinity, suspended particulate matter (SPM), suspended particulate organic matter (SPOM), $\mathrm{pH}$ and dissolved silicate (a major nutrient for marine primary production that has a terrestrial origin). The samples were collected using Go-Flo Hydrobios ${ }^{\circledR}$ bottles.

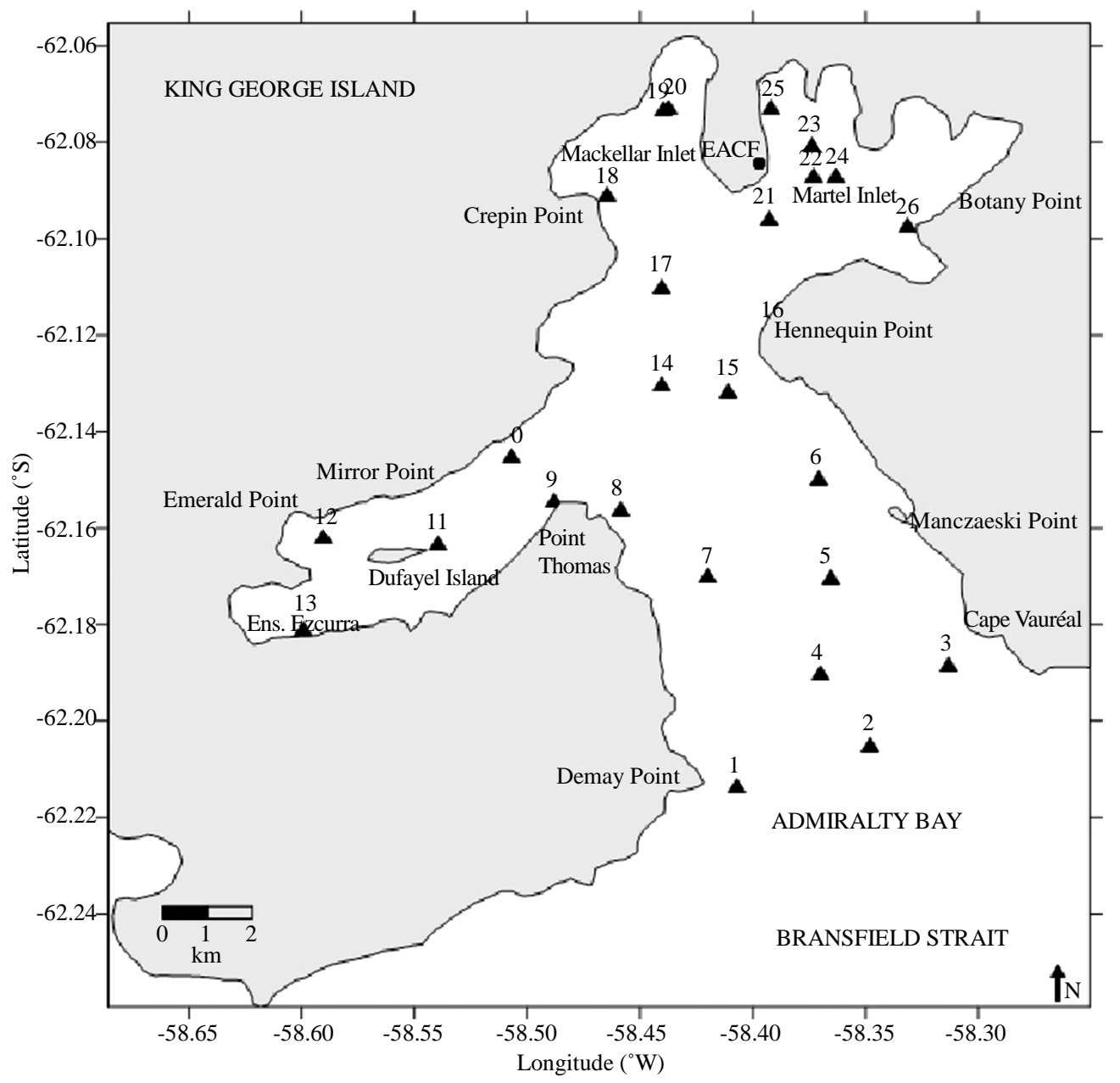

Figure 3. Sampling points in Admiralty Bay, December 2004, Antarctica. 
Salinity was measured in a Mod RS-10 Beckman ${ }^{\circledR}$ inductive salinometer with \pm 0.005 precision. An analysis of SPM and SPOM was performed using the gravimetric method described in [17] using a Whatman ${ }^{\circledR} \mathrm{GF} / \mathrm{F}$ fiberglass filter with a nominal porosity of $0.45 \mu \mathrm{m}$ and $\pm 0.01 \mathrm{mg} \cdot \mathrm{L}^{-1}$ precision. The concentration of dissolved silicate was analyzed using the colorimetric method described in [18] with a precision of $\pm 0.01 \mu \mathrm{mol} \cdot \mathrm{L}^{-1} \cdot \mathrm{pH}$ was determined using an Orion ${ }^{\circledR}$ portable $\mathrm{pH}$ meter with a precision of \pm 0.001 , and temperature was measured in situ using protected reversing thermometers, which were accurate to $\pm 0.02^{\circ} \mathrm{C}$, connected to the Go-Flo ${ }^{\circledR}$ Hydrobios bottle.

\section{Results and Discussion}

\subsection{Sediment Spatial Dispersion at Martel Inlet}

The spatial dispersion patterns of the SPM plumes were identified by digitally processed satellite images (Figure 4 and Figure 5).

The data obtained corroborate previous publications [19] and suggest a high production of fine sediments in these glaciers through subglacial flow, most likely because of melting processes that may indicate a humid basal thermal regime.

In the investigation of sediment transfer to Admiralty Bay, the role of the thermal regime, slope, flow rate conditions, topography, extent of the ice mass and degree of retraction should all be considered.

The Ajax glacier has a higher slope (Figure 6) as a function of topographical gradient but a relatively lower proportion of turbidity in its frontal zone (Figure 5).

The processed images show a turbidity zone in the proximal area of the Ajax and Stenhouse glaciers. These glaciers are characterized by an accelerated and continuous retreat process (Figure 7 and Table 1) and ice near its melting point under pressure. The glacial retreat process observed in the study area may be accompanied by an increased supply of meltwater into the glaciomarine environment, which can interfere with the local ecosystem and cause changes in salinity levels.

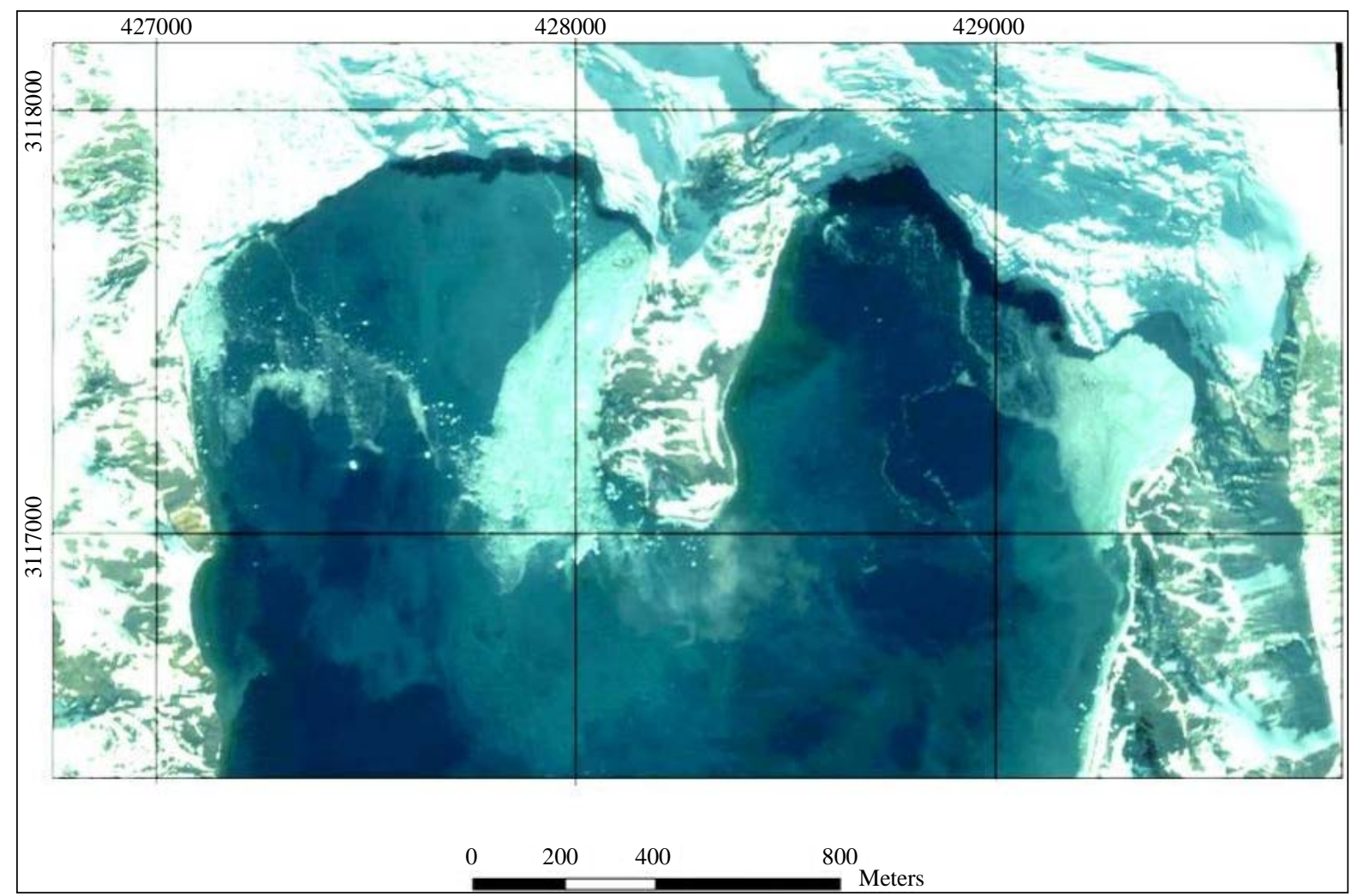

Figure 4. Stenhouse and Ajax glaciers displayed on Quickbird imagery in color composite (RGB 321) processed by linear enhancement techniques. 


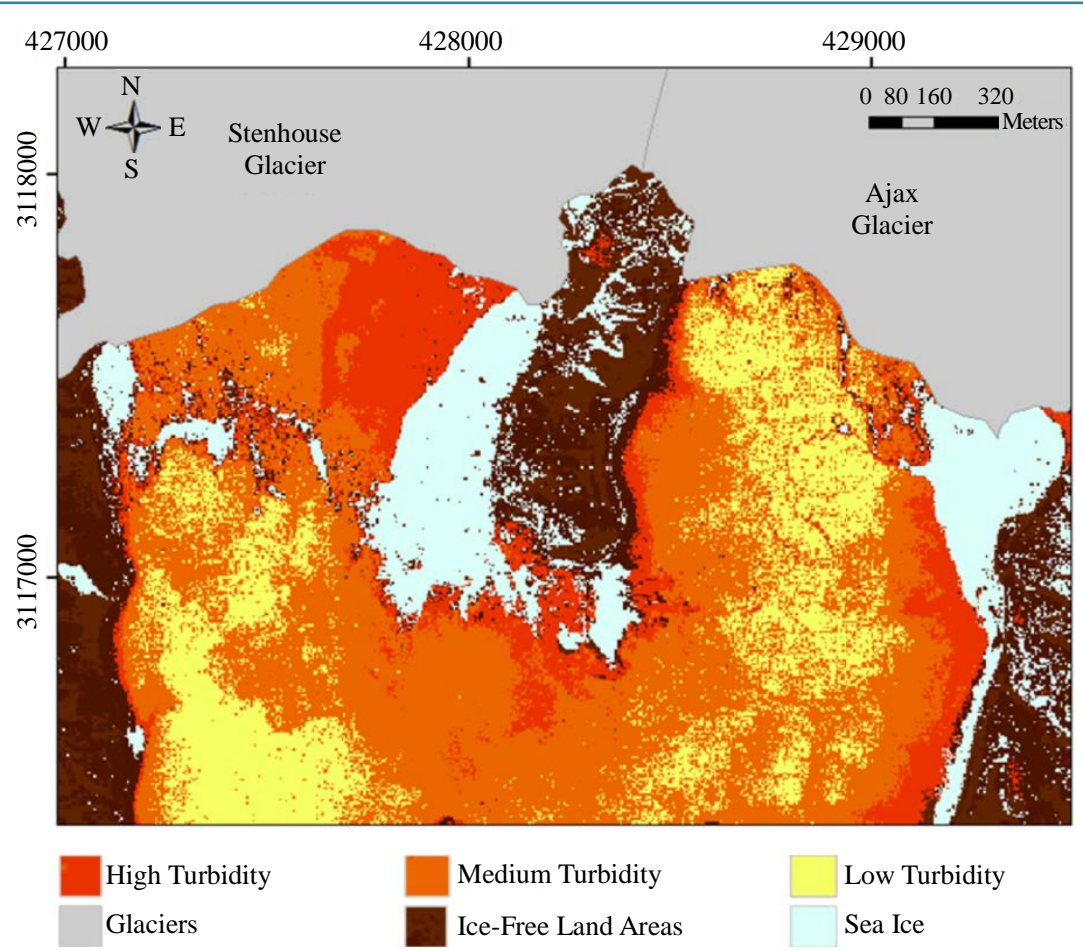

Figure 5. A classification map showing the spatial distribution of suspended particulate matter concentrations in the zone proximal to the front of the Stenhouse and Ajax glaciers, Antarctica.

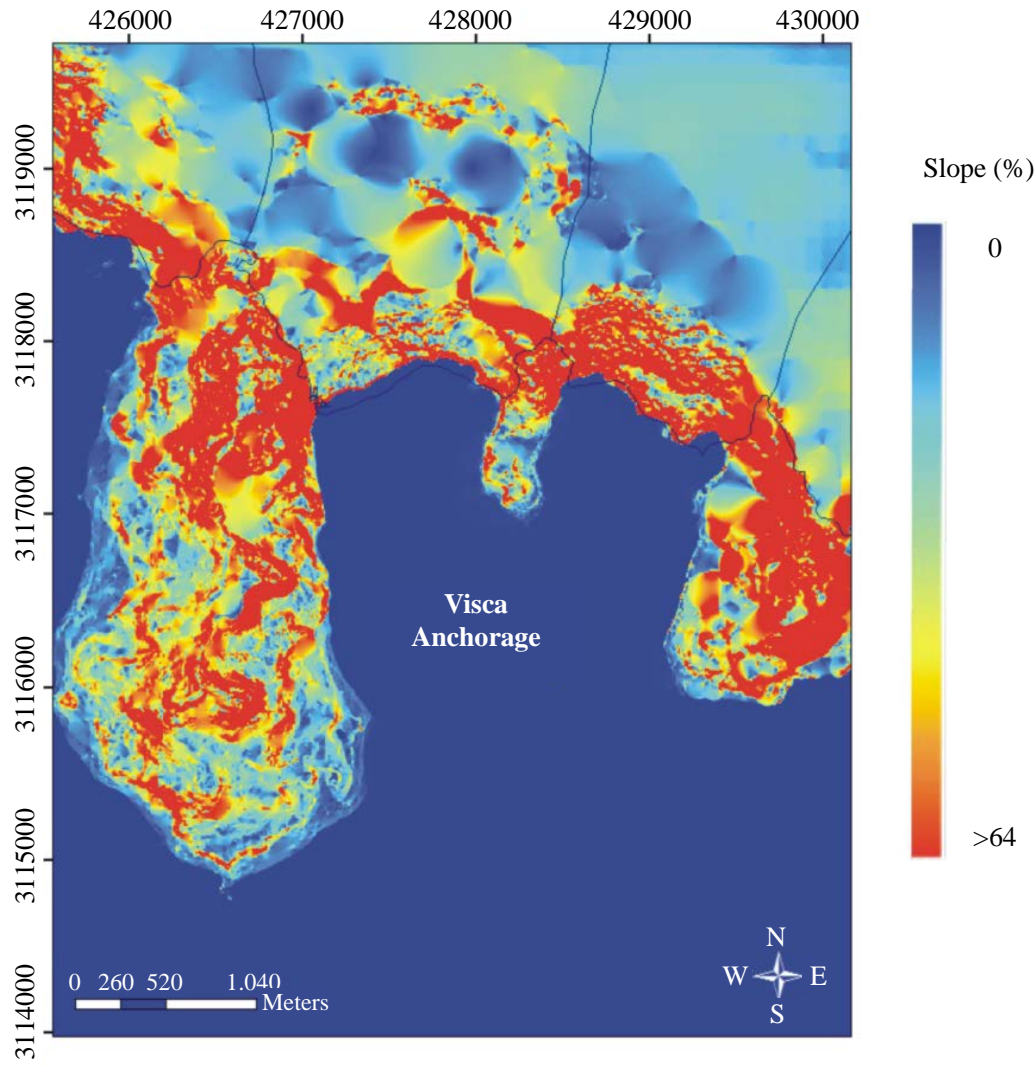

Figure 6. Map of the slope (percentage) of the study area. 


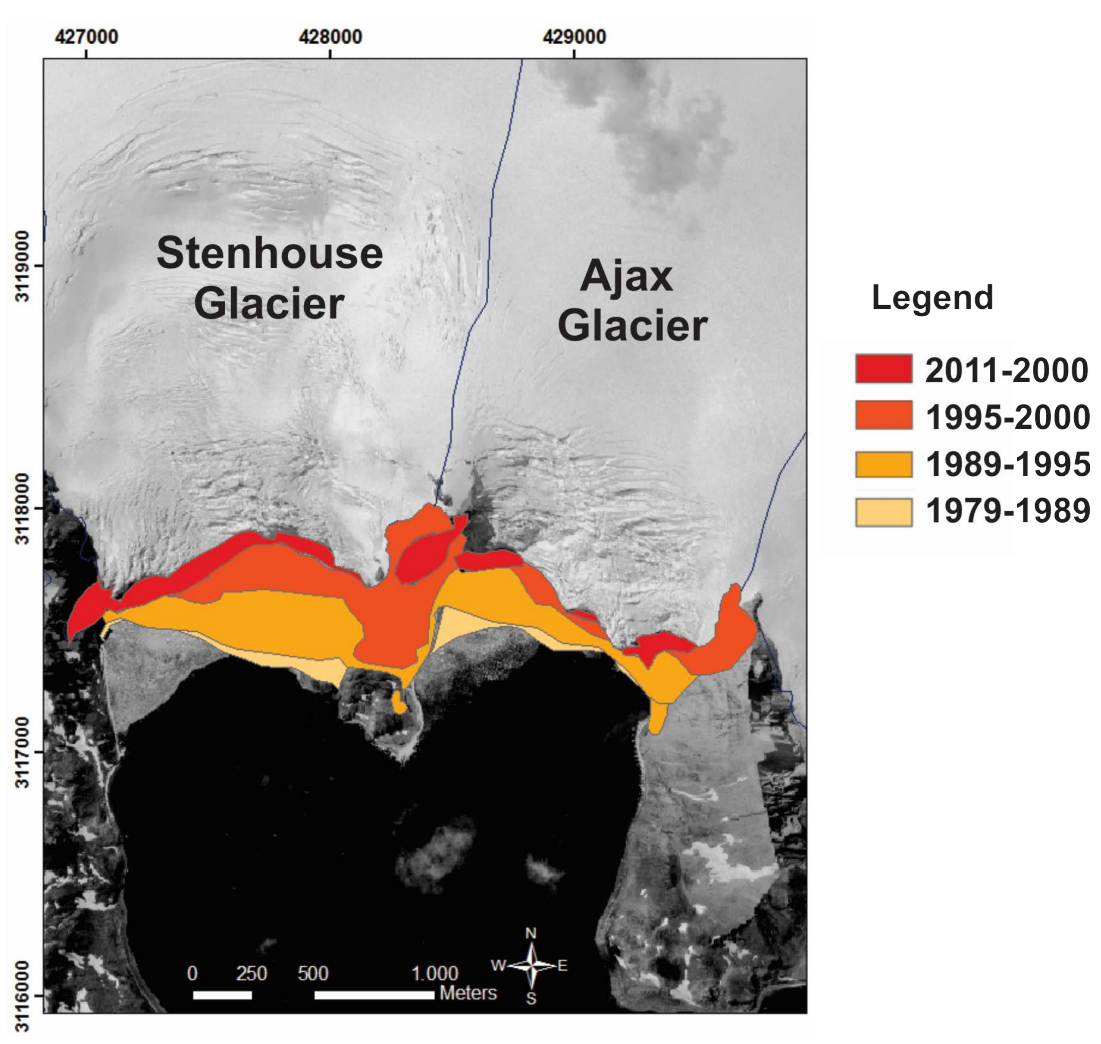

Figure 7. Map of annual retreat of the Stenhouse and Ajax glaciers, Antarctica.

Table 1. Retreat of the Ajax and Stenhouse glaciers from 1979-2011.

\begin{tabular}{|c|c|c|c|c|c|c|c|c|c|}
\hline Glacier & $\begin{array}{c}\text { Area } \\
\text { in } 1979 \\
\left(\mathbf{k m}^{2}\right)\end{array}$ & $\begin{array}{c}\text { Loss of area } \\
\text { between } \\
\text { 1979-88 }\left(\mathbf{k m}^{2}\right)\end{array}$ & $\begin{array}{c}\text { Loss of area } \\
\text { between } \\
\text { 1988-95 }\left(\mathbf{k m}^{2}\right)\end{array}$ & $\begin{array}{c}\text { Loss of area } \\
\text { between } \\
1995-00\left(\mathbf{k m}^{2}\right)\end{array}$ & $\begin{array}{c}\text { Loss of area } \\
\text { between } \\
\text { 2000-06 }\left(\mathbf{k m}^{2}\right)\end{array}$ & $\begin{array}{c}\text { Loss of area } \\
\text { between } \\
\text { 2006-11 }\left(\mathbf{k m}^{2}\right)\end{array}$ & $\begin{array}{c}\text { Area } \\
\text { in } 2011 \\
\left(\mathbf{k m}^{2}\right)\end{array}$ & $\begin{array}{c}\text { Total } \\
\text { area lost } \\
\%\end{array}$ & $\begin{array}{l}\text { Annual } \\
\text { retreat rate } \\
\mathbf{m}^{2} \mathbf{a}^{-1}\end{array}$ \\
\hline Ajax & 6.94 & 0.01 & 0.16 & 0.12 & 0.23 & 0.01 & 6.41 & 7.70 & 16 \\
\hline Stenhouse & 9.70 & 0 & 0.20 & 0.2 & 0.18 & 0.02 & 9.10 & 6.20 & 18 \\
\hline
\end{tabular}

The spatial configuration of the turbidity plume shows conditioning by currents influenced by wind. The highest concentration of suspended material occurs in the proximal zone of the Stenhouse glacier, which has a greater glacierized area, higher retreat rate, a high slope, and most likely high ice flow speed, conferring a high capacity for transporting sediment.

Differences in the suspended sediment concentrations observed according to the month in which the image was obtained should be considered because these differences demonstrate seasonal control, according to weather conditions, in the discharge processes of suspended sediment by the glaciers [12] [19]. Similarly, the distribution of suspended sediments is influenced by the tide variation process and hydrodynamic characteristics of the inlet [19].

\subsection{Hydrogeochemical Conditions}

The data obtained from the waters of Admiralty Bay in December 2004 such as temperature $\left({ }^{\circ} \mathrm{C}\right)$, $\mathrm{pH}$, salinity, dissolved silicate $\left(\mu \mathrm{mol} \cdot \mathrm{L}^{-1}\right)$, suspended particulate matter $\left(\mathrm{mg} \cdot \mathrm{L}^{-1}\right)$, organic particulate matter $\left(\mathrm{mg} \cdot \mathrm{L}^{-1}\right)$ and percentage of organic matter are illustrated in a box plot graph (Figure 8).

Water temperature ranged from $-0.85^{\circ} \mathrm{C}$ to $1.86^{\circ} \mathrm{C}$. The minimum was observed at station 25 , which was located in the inner portion of Martel Inlet next to the Stenhouse and Ajax glaciers. Salinity (Figure 9(b)) varied from 33.70 (closest to the front of the glaciers) to 34.60. The lowest salinity and temperature values were related to the influence of colder and less saline meltwaters (Figure 9(a) and Figure 9(b)). 


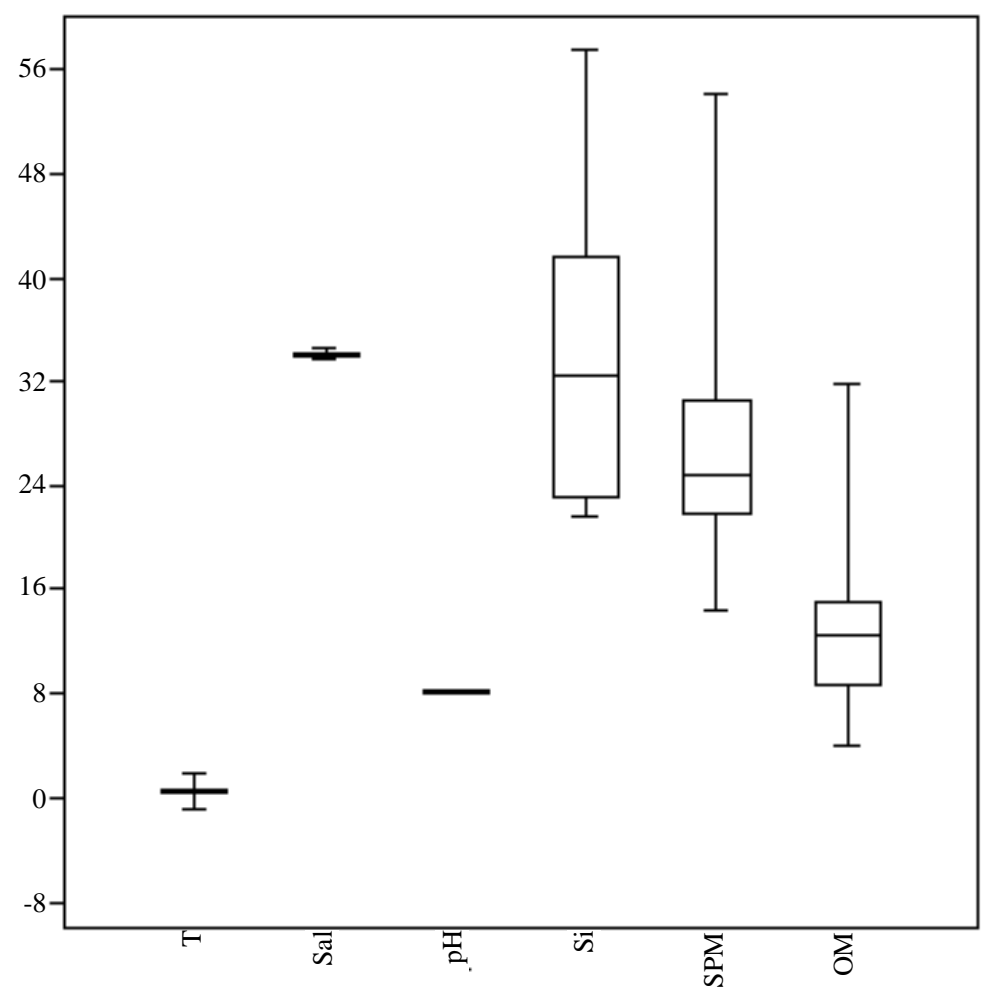

Figure 8. Box plot of hydrological parameters: temperature $\left(\mathrm{T}\right.$; $\left.{ }^{\circ} \mathrm{C}\right)$, salinity (Sal.), $\mathrm{pH}$, dissolved silicate $\left(\mathrm{Si} ; \mu \mathrm{mol} \cdot \mathrm{L}^{-1}\right)$, suspended particulate matter $\left(\mathrm{SPM} ; \mathrm{mg} \cdot \mathrm{L}^{-1}\right)$ and suspended particulate organic matter $\left(\mathrm{OM} ; \mathrm{mg} \cdot \mathrm{L}^{-1}\right)$ in Admiralty Bay, Antarctica in December 2004.

The $\mathrm{pH}$ showed a direct correlation with salinity $(\mathrm{r}=0.45$; $\mathrm{p}<0.05)$. Lower salinity and temperature values associated with $\mathrm{pH}$ values lower than 8.0 were observed within Martel and Mackellar Inlets. High levels of dissolved silicate (values ranged from $19.87 \mu \mathrm{mol} \cdot \mathrm{L}^{-1}$ to $57.54 \mu \mathrm{mol} \cdot \mathrm{L}^{-1}$ ), SPM (from $14.24 \mathrm{mg} \cdot \mathrm{L}^{-1}$ to 54.07 $\mathrm{mg} \cdot \mathrm{L}^{-1}$ ) and SPOM (from $3.90 \mathrm{mg} \cdot \mathrm{L}^{-1}$ to $31.85 \mathrm{mg} \cdot \mathrm{L}^{-1}$ ) were observed in the study area, which, in general, can be attributed to the influence of the meltwater in this region, which carries sediments to the surface layer.

During the winter, with the formation of sea ice, bodies of water have been associated with higher salinity values. The action of this mechanism tends to inhibit the settling of suspended particles. In the summer, with increased meltwater flow, salinity becomes lower, which accelerates an stratification mechanisms.

Higher concentrations of SPM were observed in Martel Inlet (stations 22 to 25) (Figure 9(e)) compared to Mackellar Inlet (stations 18 to 20), as observed by [12]. The latter authors related this result to a greater resuspension of particulates from the currents and tides because the Martel Inlet is relatively shallow (approximately $40 \mathrm{~m}$ deep) and is a periglacial area where there is a greater contribution of particulate matter into the water system by meltwater discharge. The same pattern can be observed by the high concentration of silicate in this area (Figure 9(d)).

Paraglacial processes, such as detritus flow on exposed and steep slopes, can also transfer sediment to the fjord (Figure 10).

Cluster analysis (Figure 11) showed the parameters divided into two groups based on the euclidean distance. SPM, silicate and salinity were classified in the same group, indicating that these parameters followed the same pattern, being influenced by similar processes, such as thawing and resuspension of sediments as described above.

It was observed that in the northern region of the Bay (inner section) salinity, temperature and $\mathrm{pH}$ are lower than in the south (towards the Bransfield Strait), while values of dissolved silicate, MPS and MO are higher. This can be attributed to the influence of the meltwater in this region, which carries materials for the superficial layer of the ocean. The opposite occurs in the southern portion, showing higher marine influence. 

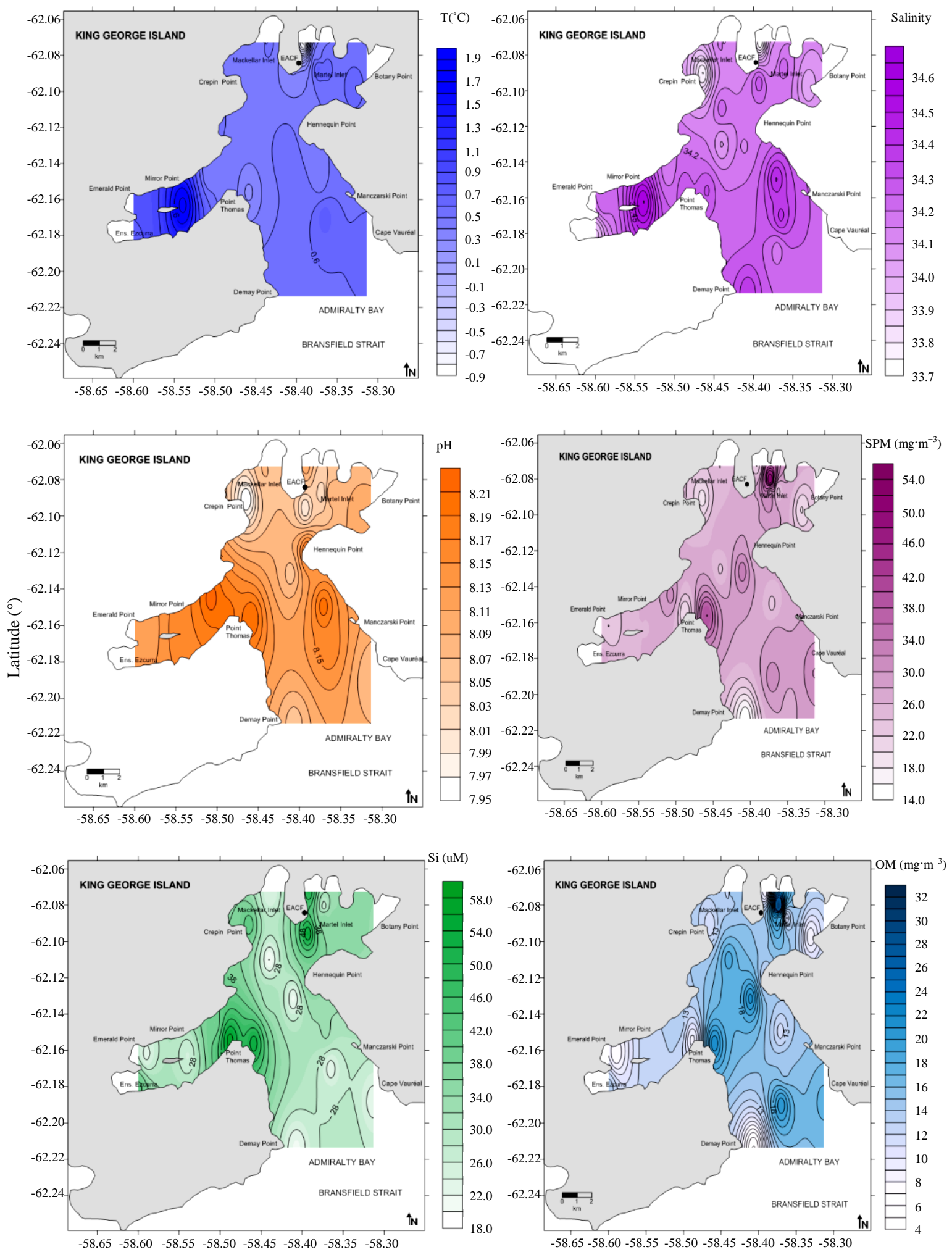

Longitude $\left(^{\circ}\right)$

Figure 9. The horizontal distribution of surface waters: temperature $\left({ }^{\circ} \mathrm{C}\right)(\mathrm{a})$, salinity (b), $\mathrm{pH}(\mathrm{c})$, dissolved silicate $\left(\mu \mathrm{mol} \cdot \mathrm{L}^{-1}\right)$ (d), suspended particulate matter (mg. $\mathrm{L}^{-1}$ ) (e) and suspended particulate organic matter (mg $\mathrm{L}^{-1}$ ) (f) in Admiralty Bay, Antarctica in December 2004. 

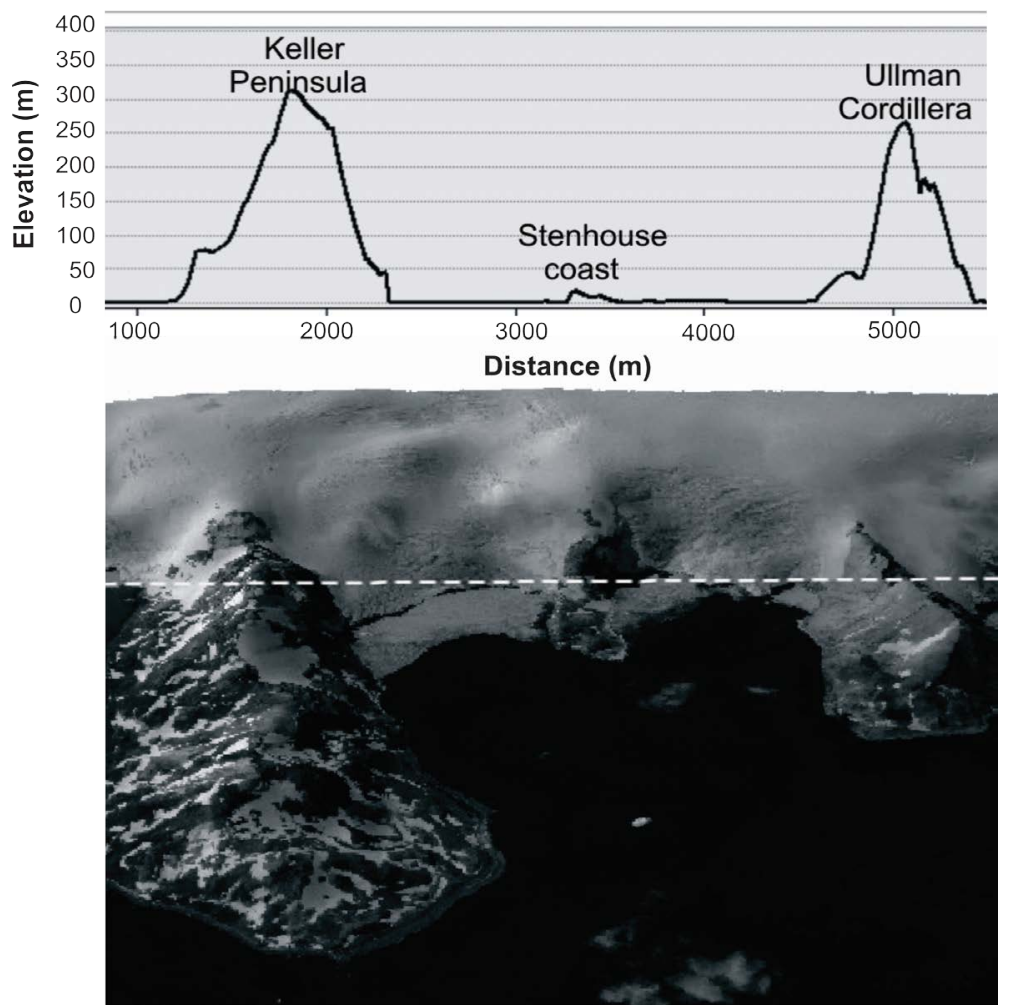

Figure 10. A longitudinal profile along the tidal glaciers shows the sector of steep exposed areas susceptible to the flow of post-depositional detritus.

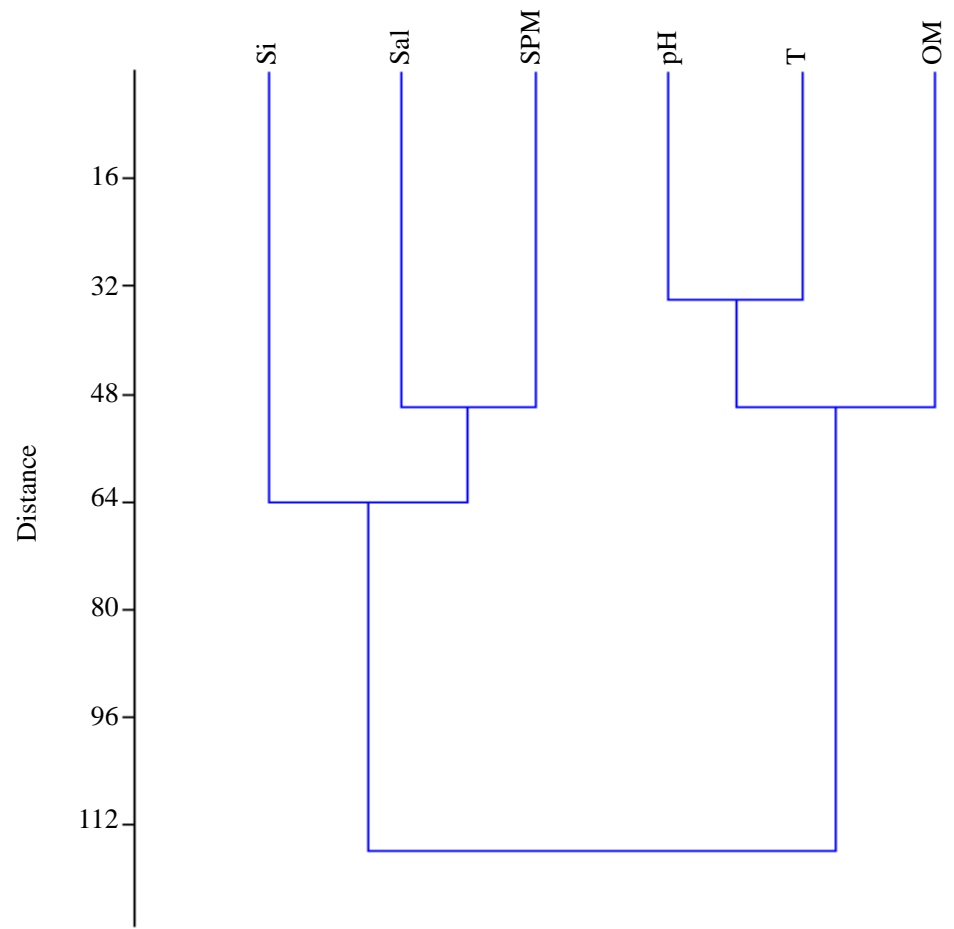

Figure 11. Cluster analysis considering the euclidean distances of the hydrological parameters: temperature (T), salinity (Sal.), $\mathrm{pH}$, dissolved silicate (Si), suspended particulate matter (SPM) and suspended particulate organic matter (OM) in Admiralty Bay, Antarctica in December 2004. 
The continental influence on the northern portion of the bay and the marine influence on the southern portion has also been reported by [20], who analyzed sediment data collected in January/February 2003. These authors observed that the elemental sediment composition was associated with particle size characteristics, reflecting their lithogenic origin associated with hydrodynamic processes in Admiralty Bay, which were less intense in more protected areas (northern portion) with important terrestrial inputs in the coastal region.

\section{Conclusions}

The processes of glacier retreat on King George Island reflected the climatic variability over recent decades and a significant inflow of suspended sediment from tidal glaciers was observed flowing into the marine environment and concentrating in some areas.

The sediment plumes identified at the surface of the inlet in the zone proximal to the front of the Stenhouse and Ajax glaciers were mainly related to the inflow of meltwater from subglacial channels, directly through the glacier terminus and via subaerial processes.

Studies monitoring these processes in the study area are important because these processes have a considerable effect on coastal marine life. The data obtained by field sampling, remote sensing and digital image processing revealed information regarding the spatial variability of SPM concentrations in glaciomarine environments. SPM concentration is one of the most important oceanographic parameters in glacial environments because its spatial distribution can be used to infer the variability of ablation processes of glaciers located in the study area and contribute to the understanding of the dynamics of oceanographic coastal processes.

Because the spatial distribution pattern of SPM concentration in front of the glaciers was linked to inflow processes from the glaciers, it was possible to investigate meltwater discharge and sediment production processes of the glaciers, thus inferring their thermal regimes. These processes may reflect the climate variability observed in the study area.

This methodology has a potential use in the monitoring of retraction-related processes, such as increased sediment inflow into the inlet associated with the discharge of meltwater. A quantitative analysis of the concentration of suspended matter in the fjord was difficult to obtain using digital image processing because the signal obtained by the sensor included information from the entire water column. It was also difficult to obtain optical images without the presence of cloud cover in the study area, which hindered the monitoring of active processes associated with glacier retreat in a temporal analysis. These processes are thus difficult to investigate and monitor because of the low temporal resolution of the images obtained, but association with data obtained in situ in the water system is an important tool to validate image processing.

\section{Acknowledgements}

This study was supported by the National Council for Scientific and Technological Development (Conselho Nacional de Desenvolvimento Científico e Tecnológico-CNPq) and was a component of the HIDROGEOQUIMBA (Hidrogeoquímica da Baía do Almirantado-Hydrogeochemistry of Admiralty Bay) Project PROANTAR-LINE 2. CNPq process number 550349/2002-2, of the Brazilian Antarctic Program and supported by the Polar and Climate Center of the Federal University of Rio Grande do Sul (Universidade Federal do Rio Grande do Sul— UFRGS).

\section{References}

[1] Simões, J.S., Ferron, F.A., Bernardo, R.T., Aristarain, A.J., Stiévenard, M., Pourchet, M. and Delmas, R.J. (2004) Ice Core Study from the King George Island, South Shetlands, Antarctica. Pesquisa Antártica Brasileira, 4, 9-23.

[2] Rakusa-Suszczewski, S. (1993) The Maritime Antarctic Coastal Ecosystem of Admiralty Bay. Polish Academy of Sciences, 27-30.

[3] Bintanja, R. (1995) Local Surface Energy Balance of the Ecology Glacier, King George Island, Antarctica: Measurements and Modeling. Antarctic Science, 7, 315-325.

[4] Braun, M., Saurer, H., Simões, J.C., Vogt, S. and Goßmann, H. (2001) The Influence of Large-Scale Atmospheric Circulation on Surface Energy Balance and Ablation on King George Island, Antarctica. International Journal of Climatology, 21, 21-36. http://dx.doi.org/10.1002/joc.563

[5] Ferrando, F.A., Vieira, R. and Rosa, K.K. (2009) Sobre el calentamiento global en la Isla Rey Jorge: Procesos y evidencias en el glaciar Wanda y su entorno. Revista Informaciones Geográficas, 41, 25-40. 
[6] Park, B.-K., Chang, S.-K., Yoon, H.I. and Chung, H. (1998) Recent Retreat of Ice Cliffs, King George Island, South Shetland Islands, Antarctic Peninsula. Annals Glaciology, 27, 633-635.

[7] Simões, J.C. and Bremer, U.F. (1995) Investigations of King George Island Ice Cover Using ERS-1/SAR and SPOT Imagery. Revista SELPER, 11, 56-60.

[8] Simões, J.C., Bremer, U.F., Aquino, F.E. and Ferron, F.A. (1999). Morphology and Variations of Glacial Drainage Basins in King George Island Icefield, Antarctica. Annals of Glaciology, 29, $220-224$. http://dx.doi.org/10.3189/172756499781821085

[9] Braun, M. and GoBmann, H. (2002) Glacial Changes in the Area of Admiralty Bay and Potter Cove, King George Island, Antarctica. In: Beyer, M. and Boelter, M. Eds., GeoEcology of Terrestrial Antarctic Oases, Springer Verlag, Berlin, 75-89.

[10] Kejna, M., Láska, K. and Caputa, Z. (1998) Recession of the Ecology Glacier in the Period 1961-1996. In: Glowacki and Bednarek, Eds., Polish Polar Studies, 25th International Polar Symposium, Warszawa, 121-128.

[11] Cook, A.J., Fox, A.J., Vaugham, D.G. and Ferrigno, J.G. (2005) Retreating Glacier Fronts on the Antarctic Peninsula over the Past Half-Century. Science, 308, 541-544. http://dx.doi.org/10.1126/science.1104235

[12] Pichlmaier, M., Aquino, F.E., Da-Silva, C.S. and Braun, M. (2004) Suspended Sediments in Admiralty Bay, King George Island (Antarctica). Revista de Pesquisa Antártica Brasileira, 4, 77-85.

[13] Pruszak, Z. (1980) Currents Circulation in the Waters of Admiralty Bay (Region of Arctowski Station on King George Island). Polish Polar Research, 1, 55-74.

[14] Domack, E.W. and Ishman, S. (1993) Oceanographic and Physiographic Controls on Modern Sedimentation within Antarctic Fjords. Geological Society of America Bulletin, 105, 1175-1189. http://dx.doi.org/10.1130/0016-7606(1993)105<1175:OAPCOM>2.3.CO;2

[15] Powell, R.D. (1990) Glacimarine Processes at Grounding-Line Fans and Their Growth to Ice-Contact Deltas. In: Dowdeswell, J.A. and Scourcse, J.D., Eds., Glacimarine Environments: Processes and Sediments, Geological Society Special Publication No. 53, London, 53-73.

[16] Wang, X., Wang, Q., Liu, G. and Li, H. (2005) A Study on the Quantitative Remote Sensing Model for the Suspended Sediment Concentration in Coastal Water with ASTER. Conference Paper, n. A290054.

[17] Strickland, J.D.H. and Parsons, T.R. (1968) A Practical Handbook of Seawater Analyses. Bulletin Fisheries Research Board of Canada, n. 167, Fisheries Research Board of Canada, Ottawa, 311 p.

[18] Grasshoff, K., Ehrardt, M. and Kremling, K. (1983) Methods of Seawater Analysis. 2nd rev. and Extended ed., Verlag Chemie, Weinheim, $419 \mathrm{p}$.

[19] Vogt, S. and Braun, M. (2004) Influence of Glaciers and Snow Cover on Terrestrial and Marine Ecosystems as Revealed by Remotely-Sensed Data. Revista de Pesquisa Antártica Brasileira, 4, 105-118.

[20] Fávaro, D.I.T., Silva, P.S.C., Mazzilli, B.P., Cavallaro, G.P.M., Taddei, M.H.T., Berbel, G.G.B. and Braga, E.S. (2012) Sediment Geochemistry in Admiralty Bay (Antarctica): Trace, Rare Earth Elements and Radionuclides. Revista de Pesquisa Antártica Brasileira, 5, 11-24. 
Scientific Research Publishing (SCIRP) is one of the largest Open Access journal publishers. It is currently publishing more than 200 open access, online, peer-reviewed journals covering a wide range of academic disciplines. SCIRP serves the worldwide academic communities and contributes to the progress and application of science with its publication.

Other selected journals from SCIRP are listed as below. Submit your manuscript to us via either submit@scirp.org or Online Submission Portal.
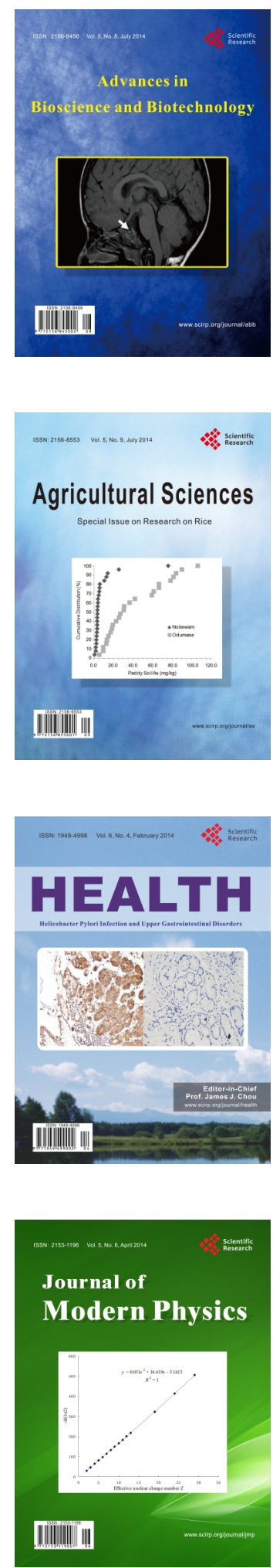
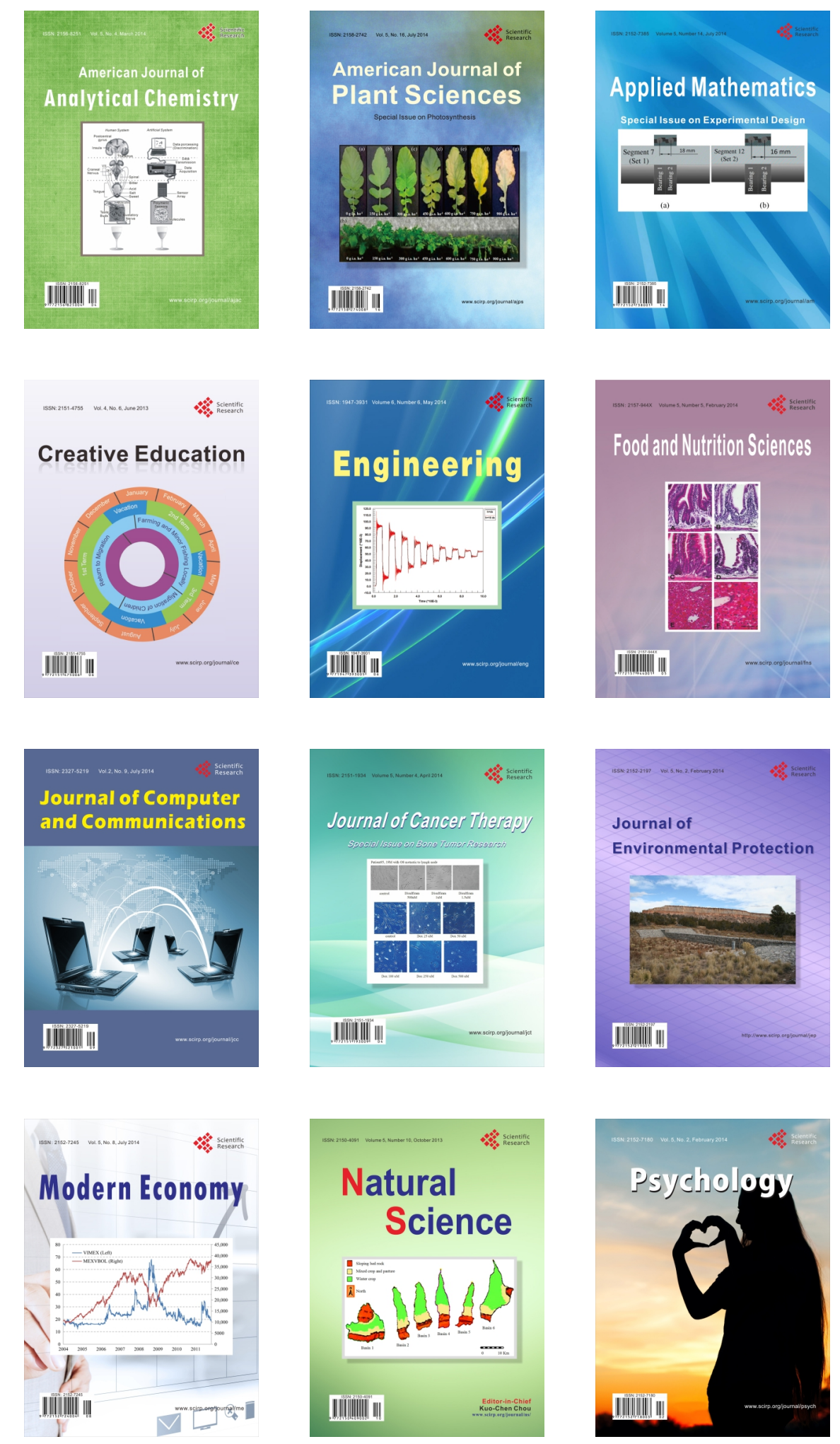